\title{
Whole body and tissue fractional protein synthesis in the ovine fetus in utero
}

\author{
BY A. L. SCHAEFER AND C. R. KRISHNAMURTI* \\ Department of Animal Science, University of British Columbia, Vancouver, B.C., \\ V6T 2A2, Canada
}

(Received 9 August 1983 - Accepted 12 April 1984)

\begin{abstract}
1. Whole-body and tissue fractional protein synthesis rates were determined in chronically-catheterized ovine fetuses at $120-130 \mathrm{~d}$ of gestation following an $8 \mathrm{~h}$ continuous infusion of $\mathrm{L}-\left[\mathrm{U}-{ }^{14} \mathrm{C}\right]-$ or $\mathrm{L}-\left[2,3,5,6-{ }^{3} \mathrm{H}\right] \mathrm{tyr}$ -

2. From the net utilization of tyrosine by the fetus, corrected for apparent oxidation, and tyrosine concentration in the fetal carcass protein, whole-body protein synthesis was estimated to be $63 \mathrm{~g} / \mathrm{d}$ per $\mathrm{kg}$.

3. Following $8 \mathrm{~h}$ of infusion of labelled tyrosine the ewes were killed and fetal tissues were removed for the determination of tyrosine specific activity. The fractional rate of protein synthesis $\left(k_{s}\right)$ was calculated from the specific activity ratio, protein bound : intracellular free tyrosine. Tissue $k_{s}$ values for the liver, kidney, lungs, brain, skeletal muscle and small intestine were $78,45,65,37,26$ and $93 \% / \mathrm{d}$ respectively.

4. The absolute rate of synthesis was calculated by multiplying the tissue protein content by $k_{s}$. Muscles, gastrointestinal tract, liver and lungs contributed approximately $20 \cdot 5,20 \cdot 5,14 \cdot 4$ and $9 \cdot 4 \%$ respectively to wholebody protein synthesis.

5. The efficiency of protein synthesis as expressed by the RNA activity was higher in liver, lung and brain followed by kidney, skeletal and cardiac muscle.
\end{abstract}

The importance of maternal nutrition and environmental conditions on the growth of the fetus and postnatal development (Robinson, 1977, 1981; Richardson, 1978; Arthur, 1981; McDonald et al. 1981; Mellor \& Murray, 1981, 1982) has led to the development of techniques for the measurement of intra-uterine growth. Morphometric changes in the sheep fetus have been measured at different stages of gestation under chronic (Mellor \& Matheson, 1979) or acute (Koong et al. 1975; Robinson \& McDonald, 1979) conditions. The rate of protein deposition in the sheep fetus has been determined by the comparative slaughter technique (Lodge \& Heaney, 1973; Rattray et al. 1974, 1975; Broad \& Davies, 1981). In addition, the retention of $\alpha$-amino-nitrogen was estimated in chronically-catheterized fetuses from umbilical veno-arterial concentration differences (Lemons et al. 1976; Faber \& Woods, 1981).

The rate of protein synthesis has also been estimated in the fetus in utero by the use of isotopic-dilution techniques (Meier et al. 1981; Noakes \& Young, 1981; Schaefer \& Krishnamurti, 1982a). This technique has been extensively used for studying the rate of whole-body protein synthesis under in vivo conditions in postnatal life in man (James et al. 1976), pig (Garlick et al. 1976; Simon et al. 1978; Reeds et al. 1980), sheep (Buttery et al. 1977; Davis et al. 1981; Bryant \& Smith, 1982) and cattle (Lobley et al. 1980).

Basically, a labelled amino acid is infused continuously into the venous system until the specific activity of the amino acid in the plasma reaches a plateau. The rate of protein synthesis is estimated from the amino acid flux (irreversible loss) after adjusting for oxidative loss. The validity of the assumptions made in the calculations and the application of the technique under a variety of nutritional states have been critically reviewed (Waterlow et al. 1978; Reeds \& Lobley, 1980).

Apart from the inherent limitation of using the plateau specific radioactivity for calculating protein synthesis, the application of this technique to the fetal system is further

\footnotetext{
* For reprints.
} 
complicated by the bidirectional transfer of nutrients between the mother and the fetus (Anand et al. 1979; Kitts \& Krishnamurti, 1982a). Under these conditions the flux, calculated from the plasma specific activity of compounds in the fetal compartment alone, would not truly reflect the unidirectional utilization by the fetus. To overcome this problem, a technique based on a two-pool kinetic model was proposed by Hodgson et al. (1980) in which differently labelled isotopes are introduced simultaneously into the maternal and fetal systems. The net utilization of substrate by the fetus is obtained from the sum of the net placental exchange and endogenous production.

Recently, we have published information (Schaefer \& Krishnamurti, 1982b) on the kinetic indices of tyrosine utilization by the sheep fetus in utero using the procedure of Hodgson et al. (1980). The objective of the present study was to use these indices in conjunction with the extent of tyrosine oxidation to estimate the whole-body and fractional $\left(k_{s}\right)$ rates of protein synthesis in the ovine fetus under in utero conditions.

\section{MATERIALS AND METHODS \\ Animals}

Fifteen Dorset $\times$ Suffolk ewes of known gestational age were used in the present study. They weighed $55-80 \mathrm{~kg}$ and were given lucerne (Medicago sativa) cubes $(\mathrm{g} / \mathrm{kg}: 196$ crude protein (nitrogen $\times 6.25$ ), 275 crude fibre) twice daily. On average the ewes consumed $1.94 \mathrm{~kg}$ cubes/d which provided $18.58 \mathrm{~kJ}$ gross energy/g. Iodized block salt and water were provided $a d$ lib. Constant fluorescent lighting was maintained and the room temperature was kept at $16^{\circ}$ (dry bulb).

\section{Surgical procedure}

To facilitate the infusion of radioactive tracers into the fetus and the ewe and withdrawal of blood, polyethylene catheters with silastic tips were inserted into the fetal inferior vena cava, pedal artery and umbilical vein as well as into the uterine vein, femoral artery and jugular vein of the ewe using the surgical procedures described previously (Kitts et al. 1979; Schaefer \& Krishnamurti, 1982a).

\section{Protein-turnover studies}

To avoid the influence of postsurgical trauma on protein turnover, infusions were carried out after a minimum of $5 \mathrm{~d}$ following surgery. The physiological stability of the preparations was verified before and during the experiment by monitoring blood gas, $\mathrm{pH}$, packed cell volume (PCV), haemoglobin and plasma metabolites (Table 1, see p. 363). The mean values reported in Table 1 are from eleven animals with triplicate observations taken for blood gas and $\mathrm{pH}$, duplicate observations for $\mathrm{PCV}$ and haemoglobin and single observations for body-weight and temperature. For blood glucose, $\alpha-\mathrm{NH}_{2}-\mathrm{N}$ and plasma lactate, values are from eight animals with duplicate observations per index. These observations were taken over an $8 \mathrm{~h}$ period during the experiment. The protocol of the isotopic infusions has been described in detail previously (Schaefer \& Krishnamurti, 1982b). Briefly, L-[U-14C]tyrosine $(50 \mu \mathrm{Ci})$ or $\mathrm{L}-\left[2,3,5,6^{3} \mathrm{H}\right]$ tyrosine $(300 \mu \mathrm{Ci})$ (New England Nuclear, Quebec) in $20 \mathrm{ml}$ sterile physiological saline ( $9 \mathrm{~g}$ sodium chloride/l) was infused into the central venous system of the fetus for $8 \mathrm{~h}$ without a priming dose at the rate of $2.2 \mathrm{ml} / \mathrm{h}$. In five preparations, when the fetus was infused with $\left[{ }^{14} \mathrm{C}\right]$ tyrosine, a simultaneous infusion of $\left[{ }^{3} \mathrm{H}\right]$ tyrosine was made into the ewe. Blood samples were withdrawn at $1 \cdot 5,3,4 \cdot 5,6,7,7 \cdot 5$ and $8 \mathrm{~h}$ from the start of infusion for the determination of plasma tyrosine specific activity. 


\section{Analysis of tissues}

For estimating the tissue $k_{\varepsilon}$, four of the fetuses were killed at the end of the infusion of tyrosine into the inferior vena cava of the fetus. The ewe was anaesthetized with sodium pentothal and the fetuses were delivered by laparotomy. The infusion was continued until the umbilical cord was ligated. The fetus was towel-dried, weighed and the whole carcass transferred to a liquid $\mathrm{N}_{2}$ container for quick freezing. The laparotomy and transfer of the fetal carcass to liquid $\mathrm{N}_{2}$ was performed as quickly as possible and the interval between the end of infusion and freezing of the fetal carcass was approximately $5 \mathrm{~min}$ in two of the preparations and less than $10 \mathrm{~min}$ in the other two. The frozen fetal carcass was placed in a container of crushed ice and tissue samples of between 3-5 g were dissected with bone scissors from the still frozen carcass and rinsed briefly in saline to remove any possible contamination with blood. For the gastrointestinal samples, care was taken to rinse the lumen side also of the tissue to remove any contamination with the lumen contents. The samples were then sectioned with dissecting scissors and scalpel to obtain subsamples which were weighed accurately and immediately placed in chilled glass homogenizing tubes to which $2 \mathrm{ml}$ refrigerated trichloroacetic acid $(100 \mathrm{~g} / 1$; TCA) were added. The glass homogenizing tubes containing the tissue subsamples were kept in 500-ml glass beakers of crushed ice during tissue homogenization to minimize proteolysis. The homogenates were centrifuged at $3000 \mathrm{~g}$ for $5 \mathrm{~min}$ after which the supernatant fraction, containing the intracellular free amino acids, was transferred to chilled 15-ml Pyrex test tubes. The pellet was washed twice with $1 \mathrm{ml}$ portions of TCA, rehomogenized and centrifuged between each washing. The combined supernatant fractions were then analysed for tyrosine concentration and radioactivity. For the determination of specific activity of tyrosine in the protein-bound amino acids, the tissue pellet was acid-hydrolysed in screw-capped test-tubes by the addition of $2 \mathrm{ml} 6 \mathrm{M}$-hydrochloric acid and placed in a $110^{\circ}$ oven for $20 \mathrm{~h}$ before tyrosine analysis. For determining the fetal whole-carcass tyrosine content, four fetuses obtained by laparotomy, were separately homogenized in an industrial blender and weighed portions of carcass homogenates were analysed for tyrosine.

\section{Analytical methods}

Haemoglobin was determined by the cyanomethaemoglobin method (Hycell Inc. Houston) and PCV by the microhaematocrit procedure. Blood glucose was analysed by the glucose oxidase (EC 1.1.3.4) procedure (Sigma Chemical Co., St Louis, Missouri). Plasma lactate was determined by the lactate dehydrogenase (EC 1.1.1.27) mehtod (Kit no. 510 and $826 \mathrm{UV}$; Sigma Chemical Co.), and $\alpha-\mathrm{NH}_{2}-\mathrm{N}$ according to the dinitrofluorobenzenederivative method of Goodwin (1968). The total $\mathrm{N}$ in the tissue samples was determined in a Technicon AutoAnalyzer (Model II; Technicon Instrument Corp., Terrytown, N.Y.) following wet acid-digestion. DNA concentration in tissue samples was determined according to the method of Gold \& Shochat (1980) and RNA by the modified SchmidtThannhauser technique (Cheek, 1975). DNA standards were prepared from calf-thymus DNA (Mann Research Laboratories, N.Y.) and RNA standards were obtained from the Sigma Chemical Co.

L-Tyrosine was quantitatively converted to tyramine by the addition of tyrosine decarboxylase (EC 4.1.1.25; Sigma Chemical Co.). The tyramine was extracted by the procedure of Garlick \& Marshall (1972) with modifications as described by Schaefer \& Krishnamurti $(1982 c)$ which improved the precision, accuracy and sensitivity. Fluorometric determination was carried out according to the procedure of Ambrose (1974). Radioactivity of tyrosine was measured by placing $1 \mathrm{ml}$ of the extracted tyramine solution into $10 \mathrm{ml}$ scintillation fluor (PCS; Amersham, Arlington Heights, Ill.) and counted in a Packard 


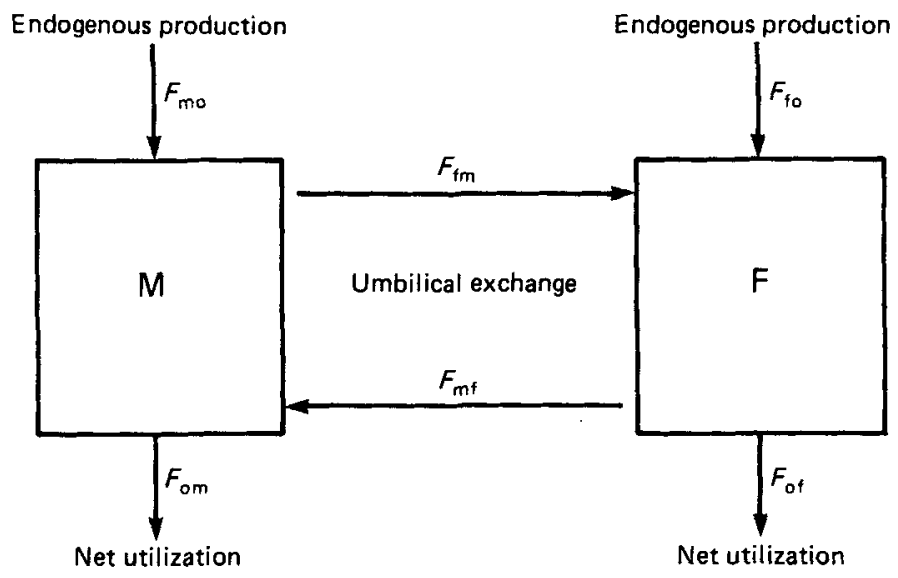

Fig. 1. Two pool model describing the kinetics of maternal - fetal tyrosine transfer. M, ewe (maternal tissues plus placenta); F, fetus; $F_{\mathrm{fo}}$ (fetus) and $F_{\mathrm{mo}}$ (ewe), endogenous production rates; $F_{\text {of }}$ (fetus) and $F_{\text {om }}\left(\right.$ ewe), net utilization rates; $F_{\mathrm{pm}}$ and $F_{\mathrm{mp}}$, placental exchange from ewe to fetus and from fetus to ewe respectively (after Schaefer \& Krishnamurti, 1982b). Net placental exchange $=F_{\mathrm{fm}}-F_{\mathrm{mp}}$. Fetal net utilization rate $=\left(F_{\mathrm{fm}}-F_{\mathrm{mf}}\right)+F_{\mathrm{fo}}$.

liquid-scintillation counter (model A $300 \mathrm{C}$ ). The determination of specific activity of blood ${ }^{14} \mathrm{CO}_{2}$ was estimated according to procedures previously described (Kitts \& Krishnamurti, $1982 b$; Schaefer \& Krishnamurti, 1982 b). The retention of labelled bicarbonate and other intermediates from tyrosine oxidation in the fetal tissues was not considered and the values of tyrosine catabolism calculated from blood ${ }^{14} \mathrm{CO}_{2}$ refer to apparent tyrosine oxidation.

\section{Calculations}

The rate of whole-body protein synthesis was calculated by dividing the net rate of utilization of tyrosine, corrected for apparent oxidation, by the tyrosine content of the fetal carcass protein.

Rate of protein synthesis $(\mathrm{g} / \mathrm{d}$ per $\mathrm{kg})=\frac{\text { Net utilization of tyrosine }- \text { tyrosine oxidized }}{\text { Tyrosine content of fetal carcass protein }}$.

The net utilization rate is the sum of net placental exchange and endogenous production (Fig. 1) and was calculated from the plateau specific activity of tyrosine in the maternal and fetal compartments following the continuous infusion of the $\left[{ }^{3} \mathrm{H}\right]$ tyrosine in the ewe and $\left[{ }^{14} \mathrm{C}\right]$ tyrosine in the fetus. The details of the kinetic procedure and determination of extent of tyrosine oxidation have been described (Schaefer \& Krishnamurti, 1982b).

The $k_{s}$ in the tissues was calculated according to two procedures. The first procedure was according to the method of Waterlow et al. (1978) using the following equations:

for muscle

$$
S_{\mathrm{B}} / S_{\mathrm{i}}=\frac{R}{R-1} \cdot \frac{1-\mathrm{e}^{-k_{g} t}}{1-\mathrm{e}^{-R k_{g} t}}-\frac{1}{R-1},
$$

for liver, brain, kidney, gastrointestinal and lung tissues

$$
S_{\mathrm{B}} / S_{\mathrm{i}}=\frac{\lambda \mathrm{i}}{\lambda \mathrm{i}-k_{s}} \cdot \frac{1-\mathrm{e}^{-k_{s} t}}{1-\mathrm{e}^{-\lambda \mathrm{i} t}}-\frac{k_{s}}{\lambda \mathrm{i}-k_{s}},
$$

where $S_{\mathrm{B}}$ is the specific activity of protein-bound tyrosine, $S_{\mathrm{i}}$ is the specific activity of intracellular free tyrosine, $\lambda i$ is the rate constant of turnover of tyrosine in the intracellular 
Table 1. Mean physiological indices for the fetus and ewe

\begin{tabular}{|c|c|c|c|c|}
\hline \multirow[b]{2}{*}{ Index } & \multicolumn{2}{|c|}{ Fetus* } & \multicolumn{2}{|c|}{ Ewe† } \\
\hline & Mean & $\mathbf{S E}$ & Mean & $\mathbf{S E}$ \\
\hline Blood pH & 7.39 & 0.03 & 7.49 & 0.04 \\
\hline Blood $\mathrm{P}_{\mathrm{Co}}(\mathrm{mmHg})$ & $33 \cdot 72$ & 1.80 & $28 \cdot 31$ & 1.25 \\
\hline Blood $\mathrm{P}_{\mathrm{O}}(\mathrm{mmHg})$ & $16 \cdot 46$ & 1.75 & 24.98 & 0.60 \\
\hline PCV & $0 \cdot 3440$ & 0.0143 & 0.3207 & 0.0106 \\
\hline $\mathrm{Hb}(\mathrm{g} / \mathrm{l})$ & $101 \cdot 2$ & $4 \cdot 8$ & $113 \cdot 2$ & $4 \cdot 1$ \\
\hline Body temperature $^{(0)}$ & - & - & 38.84 & $0 \cdot 12$ \\
\hline Body-wt $(\mathrm{kg}) \ddagger$ & 1.78 & $0 \cdot 18$ & $65 \cdot 72$ & $2 \cdot 71$ \\
\hline Plasma glucose $(\mathrm{mg} / \mathrm{l})$ & $125 \cdot 5$ & 15.6 & 601.8 & $52 \cdot 1$ \\
\hline Plasma $\alpha$-amino-nitrogen $(\mathrm{mg} / \mathrm{l})$ & 133.8 & $7 \cdot 0$ & 106.8 & $4 \cdot 2$ \\
\hline Plasma lactate $(\mathrm{mg} / \mathrm{l})$ & $129 \cdot 8$ & $12 \cdot 6$ & 55.8 & $7 \cdot 3$ \\
\hline
\end{tabular}

PCV, packed cell volume; $\mathrm{Hb}$, haemoglobin.

* Fetal blood samples were obtained from the inferior vena cava.

$\dagger$ Ewe blood samples were obtained from the jugular vein.

$\ddagger$ Predicted fetal body-weight at date of experiment based on the regression formula of Gresham et al. (1972).

free pool (in liver $\lambda \mathrm{i}=\lambda \mathrm{p}$ or the rate constant of turnover of the infused tyrosine in the plasma; in muscle $\left.\lambda \mathrm{i}=R k_{s}\right), k_{s}$ is the fractional synthetic rate, $t$ is the time of infusion (d), $\mathrm{e}^{s}=2 \cdot 7182, R$ is the ratio protein-bound:intracellular free tyrosine, $S_{\mathrm{p}}$ is the specific activity in plasma.

In the second procedure the values for tissue $k_{s}$ were calculated by substituting $S_{\mathrm{B}} / S_{\mathrm{p}}$ for $S_{\mathrm{B}} / S_{\mathrm{i}}$ in eqns (1) and (2). These methods of calculating tissue $k_{s}$ provide estimates of maximum and minimum rates respectively as shown in Table 3 (see p. 364). The advantages and disadvantages of both methods are discussed later.

\section{Statistical analysis}

The differences among tissue indices were determined using the analysis of variance and the differences tested for significance by the Newman-Keuls multiple range test (Steel \& Torrie, 1960). Bartlett's test of homogeneity of variances (Sokal \& Rohlf, 1969) revealed that heterogeneity was evident in the data for tissue protein-bound tyrosine concentration $(\mathrm{mg} / \mathrm{g})$ and RNA concentration $(\mathrm{mg} / \mathrm{g})$. Therefore, these particular data were statistically analysed using appropriate ANOVA tests for data with heterogeneous variances as per the procedures of Sokal \& Rohlf (1969).

\section{RESULTS}

The blood indices of the fetus and ewe at the time of experimentation (Table 1) are within the physiological range reported for fetuses which have been catheterized (Comline \& Silver, 1970; Battaglia \& Meschia, 1978; Kitts et al. 1979).

The plateau specific activity ratio, intracellular free tyrosine $\left(S_{\mathrm{i}}\right)$ : plasma free tyrosine $\left(S_{p}\right)$ was low $(0 \cdot 14-0 \cdot 19)$ in liver, small intestine, lung, brain and kidney and high $(0 \cdot 45-0 \cdot 62)$ in skeletal and cardiac muscles (Table 2), $S_{\mathrm{B}}: S_{\mathrm{p}}$ in all tissues was lower than the corresponding $S_{\mathrm{B}}: S_{\mathrm{i}}$ values. The protein turnover in the liver and small intestine was more rapid than in the other tissues as indicated by the shorter half-life of mixed proteins (Table 3).

The net utilization of tyrosine by the fetal tissues as reported by Schaefer \& Krishnamurti 
Table 2. Relative plateau specific activity of $\left[{ }^{3} \mathrm{H}\right]$ tyrosine in different tyrosine pools (Mean values with their standard errors)

\begin{tabular}{|c|c|c|c|c|c|c|}
\hline \multirow[b]{2}{*}{ Tissue } & \multicolumn{2}{|c|}{$S_{1}: S_{\mathrm{p}}$} & \multicolumn{2}{|c|}{$S_{\mathrm{B}}: S_{\mathrm{p}}$} & \multicolumn{2}{|c|}{$S_{\mathrm{B}}: S_{\mathrm{i}}$} \\
\hline & Mean & SE & Mean & SE & Mean & SE \\
\hline Liver & 0.139 & 0.056 & 0.021 & 0.009 & $0 \cdot 201$ & 0.027 \\
\hline Small intestine & 0.152 & 0.055 & 0.031 & 0.009 & 0.238 & 0.062 \\
\hline Lung & $0 \cdot 139$ & 0.059 & 0.022 & 0.011 & $0 \cdot 174$ & $0 \cdot 047$ \\
\hline Brain & 0.189 & 0.042 & 0.018 & 0.007 & $0 \cdot 103$ & 0.036 \\
\hline Kidney & 0.152 & 0.048 & 0.021 & 0.012 & $0 \cdot 126$ & 0.032 \\
\hline Skeletal muscle & 0.449 & 0.209 & 0.013 & 0.006 & 0.029 & 0.008 \\
\hline Cardiac muscle & 0.619 & 0.181 & 0.019 & 0.005 & 0.032 & 0.006 \\
\hline
\end{tabular}

$S_{\mathrm{i}}$, specific activity of intracellular free tyrosine; $S_{\mathrm{B}}$, specific activity of protein-bound tyrosine; $S_{\mathrm{p}}$, specific activity of plasma tyrosine.

Table 3. Fractional $(\% / d)$ and absolute rate of protein synthesis in fetal tissues

\begin{tabular}{|c|c|c|c|c|c|c|c|c|c|c|c|c|}
\hline \multirow[b]{2}{*}{ Tissue } & \multicolumn{2}{|c|}{$\begin{array}{l}\text { Mean wt } \\
\text { (g) }\end{array}$} & \multicolumn{2}{|c|}{$\begin{array}{l}\text { Protein } \\
(\mathrm{mg} / \mathrm{g})\end{array}$} & \multirow{2}{*}{$\begin{array}{l}\text { Total } \\
\text { protein } \\
\text { (g) }\end{array}$} & \multicolumn{4}{|c|}{$\begin{array}{c}\text { Fractional }\left(k_{g}\right) \\
\text { synthetic rate }(\% / \mathrm{d})\end{array}$} & \multirow{2}{*}{$\begin{array}{l}\text { Half-life } \\
\text { (d) }\end{array}$} & \multirow{2}{*}{$\begin{array}{l}\text { Absolute } \\
\text { rateł of } \\
\text { synthesis } \\
(\mathrm{g} / \mathrm{d})\end{array}$} & \multirow{2}{*}{$\begin{array}{c}\text { Percentage of } \\
\text { whole-body } \\
\text { synthesis }\end{array}$} \\
\hline & Mean & $\mathbf{S E}$ & Mean & $\mathbf{S E}$ & & Min & SE & Max & SE & & & \\
\hline Heart & $20 \cdot 1$ & 2.6 & 141 & 4 & $2 \cdot 8$ & $11 \cdot 2$ & $3 \cdot 0$ & $14 \cdot 0$ & 3.0 & 4.950 & 0.40 & 0.6 \\
\hline Muscle* & 374 & - & 133 & 3 & $49 \cdot 7$ & $10 \cdot 3$ & $3 \cdot 4$ & $26 \cdot 0$ & $7 \cdot 0$ & $2 \cdot 665$ & 12.93 & $20 \cdot 5$ \\
\hline Liver & $72 \cdot 1$ & $7 \cdot 0$ & 160 & 4 & $11 \cdot 6$ & $9 \cdot 5$ & $5 \cdot 2$ & $78 \cdot 0$ & $15 \cdot 0$ & 0.888 & $9 \cdot 06$ & 14.4 \\
\hline Brain & $38 \cdot 2$ & $2 \cdot 8$ & 71 & 4 & $2 \cdot 7$ & $14 \cdot 2$ & $3 \cdot 1$ & $37 \cdot 3$ & $18 \cdot 7$ & 1.690 & $1 \cdot 01$ & $1 \cdot 6$ \\
\hline Lung & $67 \cdot 5$ & $7 \cdot 3$ & 135 & 8 & $9 \cdot 1$ & $12 \cdot 8$ & 6.9 & $65 \cdot 0$ & $16 \cdot 0$ & 1.066 & 5.92 & $9 \cdot 4$ \\
\hline Kidney & $20 \cdot 0$ & $3 \cdot 5$ & 114 & 6 & $2 \cdot 3$ & $10 \cdot 5$ & 4.9 & $44 \cdot 6$ & $11 \cdot 8$ & 1.540 & 1.02 & 1.6 \\
\hline $\mathrm{GIT}^{\dagger}$ & 122 & - & 148 & 4 & $18 \cdot 1$ & $17 \cdot 6$ & $4 \cdot 1$ & $71 \cdot 2$ & $25 \cdot 7$ & 0.707 & 12.90 & $20 \cdot 5$ \\
\hline
\end{tabular}

GIT, gastrointestinal tract; Min, Max, minimum and maximum rates of tissue fractional protein synthesis using specific activity ratios, protein-bound tyrosine:plasma tyrosine or protein-bound tyrosine:intracellular free tyrosine.

* Based on fetal carcass dissection, muscles were found to contribute $21 \%$ of body-weight.

$\uparrow$ GIT weight includes reticulum, rumen, omasum, abomasum, small intestine and large intestine. $k_{s}$ For GIT refers to mean values of small intestine and reticulum-rumen only.

$\ddagger$ Total protein $\times k_{8}$ Max.

Table 4. The concentration of tyrosine and nucleic acids in fetal tissues

\begin{tabular}{|c|c|c|c|c|c|c|}
\hline \multirow[b]{2}{*}{ Tissue } & \multicolumn{2}{|c|}{$\begin{array}{l}\text { Protein-bound } \\
\text { tyrosine (mg/g) }\end{array}$} & \multicolumn{2}{|c|}{ RNA (mg/g) } & \multicolumn{2}{|c|}{ DNA (mg/g) } \\
\hline & Mean & SE & Mean & $\mathbf{S E}$ & Mean & SE \\
\hline Liver & $5 \cdot 49^{\mathrm{a}}$ & 0.474 & $8 \cdot 80^{\mathrm{a}}$ & 0.95 & $2 \cdot 62^{\mathrm{c}}$ & 0.40 \\
\hline Lung & $2 \cdot 52^{\mathrm{ed}}$ & 0.277 & $5.94^{\mathrm{b}}$ & 0.38 & $4 \cdot 45^{\mathrm{ab}}$ & 0.69 \\
\hline Kidney & $2 \cdot 19^{d}$ & 0.258 & $4 \cdot 69^{\mathrm{bc}}$ & 0.55 & $5 \cdot 15^{a}$ & 0.63 \\
\hline Brain & $2 \cdot 24^{\mathrm{d}}$ & 0.072 & $1.90^{\mathrm{d}}$ & 0.08 & $3 \cdot 11^{\mathrm{bc}}$ & 0.43 \\
\hline Skeletal muscle & $3.66^{\mathrm{bc}}$ & 0.078 & $3 \cdot 36^{\mathrm{cd}}$ & 0.15 & $2 \cdot 43^{\mathrm{c}}$ & 0.37 \\
\hline Cardiac muscle & $3 \cdot 33^{\text {bed }}$ & 0.271 & $3.60^{\mathrm{c}}$ & 0.28 & $3 \cdot 61^{\mathrm{abc}}$ & 0.29 \\
\hline
\end{tabular}

a, b, c, d Means with different superscript letters within vertical columns were significantly different $(P<0 \cdot 0$ l $)$. 
Table 5. Protein synthetic capacity and activity in fetal tissues

\begin{tabular}{lcccc}
\hline Tissue & RNA:DNA & Protein:DNA & Protein: RNA & $\begin{array}{c}\text { RNA activity } \\
\text { (g protein/g RNA per d) }\end{array}$ \\
\hline Liver & $3 \cdot 36^{\mathrm{a}}$ & $61 \cdot 11^{\mathrm{a}}$ & $18 \cdot 19$ & 14.3 \\
Lung & $1.34^{\mathrm{bc}}$ & $30 \cdot 40^{\mathrm{b}}$ & $22 \cdot 76$ & 14.8 \\
Kidney & $0.91^{\mathrm{bed}}$ & $22 \cdot 17^{\mathrm{b}}$ & 24.33 & 10.9 \\
Brain & $0.61^{\mathrm{ed}}$ & $22 \cdot 88^{\mathrm{b}}$ & 37.47 & $15 \cdot 3$ \\
Skeletal muscle & $1.38^{\mathrm{b}}$ & $54 \cdot 41^{\mathrm{a}}$ & 39.43 & $10 \cdot 3$ \\
Cardiac muscle & $0.99^{\mathrm{bcd}}$ & $39 \cdot 81^{\mathrm{b}}$ & 39.89 & 5.6 \\
\hline
\end{tabular}

$a, b, c, d$ Means with different superscript letters within vertical columns were significantly different $(P<0 \cdot 05)$.

(1982b) was $6.536 \mathrm{mmol} / \mathrm{d}$ per $\mathrm{kg}$ of which 5.2 (SE 1.65$) \%$ was used for apparent oxidation leaving $6.196 \mathrm{mmol} / \mathrm{d}$ per $\mathrm{kg}$ for synthesis of proteins. From the tyrosine content of the entire fetal carcass protein $(15.71$ (SE 1.30$) \mathrm{mmol} / \mathrm{kg}$ ) the whole-body rate of protein synthesis can be calculated to be $63 \mathrm{~g} / \mathrm{d}$ per $\mathrm{kg}$.

The fractional rate of protein synthesis (Table 3 ) was relatively low in cardiac and skeletal muscles and high in small intestine, liver and lung with the kidney and brain occupying an intermediate position. The absolute rate of protein synthesis in individual tissues $(\mathrm{g} / \mathrm{d})$ was calculated by multiplying the total protein content of the tissue by $k_{s}$ (Table 3). Though $k_{s}$ of skeletal muscles was only $26 \% / \mathrm{d}$, the total amount of protein synthesized in the muscles $(12.93 \mathrm{~g} / \mathrm{d})$ was higher than in any other single tissue. The absolute rates were also high in liver and gastrointestinal tract which synthesized 9.06 and $12.90 \mathrm{~g} / \mathrm{d}$ respectively.

The tyrosine and nucleic acid concentrations in fetal tissues are presented in Table 4 . The concentrations of tyrosine and RNA were higher in liver than in any other tissue, while the DNA concentration was relatively low. Skeletal and cardiac muscles also had a high concentration of tyrosine. The RNA concentrations in the lung and kidney were higher than in the muscles and brain. Kidney and lung had the highest concentration of DNA among the tissues analysed. The efficiency of protein synthesis was expressed as the amount of protein synthesized per unit RNA per d (Table 5). The efficiency was high in liver, lung and brain followed by kidney, skeletal and cardiac muscle.

\section{DISCUSSION}

Protein synthesis in the fetus has recently been studied by the continuous infusion of labelled lysine (Noakes \& Young, 1981; Meier et al. 1981). However, the use of labelled lysine necessitates a rather lengthy infusion period of between 9 and $13 \mathrm{~h}$ as reported by Meier et al. (1981). The choice of labelled tyrosine in the current study was based on its smaller pool size than lysine in the fetal plasma (Lemons et al. 1976) so that the plateau specific activity is reached more rapidly. As reported earlier (Schaefer \& Krishnamurti, 1982b) the slope of the specific activity $v$. time curve was approximately zero after $6 \mathrm{~h}$ of infusion. It was considered important to minimize the stress on the chronic fetal preparation by keeping the duration of infusion as short as possible. In addition, under our conditions, the modified fluorometric analysis procedure for tyrosine (Schaefer \& Krishnamurti, 1982c) was found to be more accurate and precise than the original method of Garlick \& Marshall (1972).

The limitations of using the tyrosine flux based on plasma specific activity for the estimation of whole-body protein synthesis have been reviewed (Waterlow et al. 1978). The fetal system is further confounded by the high turnover as well as the possibility of bidirectional transfer of the label across the placenta. In order to overcome this problem, 
the net utilization of tyrosine by the fetus was estimated by adding the net placental transfer and endogenous production using the two-pool kinetic model as described by Hodgson et al. (1980). From the net utilization rate, the amount of tyrosine used for apparent oxidative purposes is deducted and the remainder is assumed to be used for protein synthesis. While some of the tyrosine-C will undoubtedly be used for non-oxidative, non-protein purposes, this quantity has been suggested to be quite small (Faber \& Woods, 1981). Furthermore, the use of tyrosine for catecholamines, thyroid hormones and melanin production, which was not measured, is assumed to be quantitatively negligible (Garlick et al. 1976).

In order to calculate tissue $k_{s}$ values accurately the use of the immediate precursor amino acyl tRNA specific activity is desired. However, technical limitations to this approach have encouraged workers to make use of alternative procedures (Garlick \& Marshal, 1972; Waterlow et al. 1978) whereby the specific activity of the labelled amino acid in the plasma or the intracellular free compartments is used. As discussed by Waterlow et al. (1978) and Zak et al. (1979) the most conventional approach in this regard is to use the intracellular free specific activity as representing the precursor specific activity. However, depending on the tissue concerned, the precursor pool may in fact be more accurately represented by the extracellular specific activity in the plasma as certain tRNA species appear to be charged preferentially from the plasma extracellular pool rather than the intracellular free pool. Furthermore, because of the unavoidable time-lag between the cessation of the isotope infusion and the freezing of tissues, there could possibly be a loss of radioactivity from the intracellular free amino acid pool which may bias the subsequent protein synthesis calculations. In view of the uncertainty in general of the precise precursor specific activity pool that is considered most representative and also the possible loss of intracellular radioactivity following the cessation of the infusion, estimates were made of minimum and maximum tissue $k_{s}$ using $S_{\mathrm{B}}: S_{\mathrm{p}}$ and $S_{\mathrm{B}}: S_{\mathrm{i}}$ values respectively at steady-state (Table 3 ). The true value is likely to lie between these two extremes as has been reported by Davis $e t$ al. (1981).

The ratio, $S_{\mathrm{i}}: S_{\mathrm{p}}$ indicates the extent of dilution of the infused label by unlabelled tyrosine arising from protein degradation. It is noteworthy that the extent of dilution varies in different tissues. In muscles, for example, the specific activity ratio, intracellular free tyrosine: plasma free tyrosine was 0.45-0.62 which is similar to the value of 0.46 in the fetus (Noakes \& Young, 1981) and 0.49 in the mature sheep (Bryant \& Smith, 1982). On the other hand, the ratio, $S_{\mathrm{i}}: S_{\mathrm{p}}$ in the liver $(0 \cdot 14)$ is much lower than the values reported in the fetus $(0.42$; Noakes \& Young, 1981) or in growing lambs $(0.30$; Davis et al. 1981). The short half-life of the mixed proteins in the liver and small intestine (Table 3) indicates a rapid turnover in these tissues resulting in greater dilution of the label in the intracellular pool. The intracellular pool in the skeletal and cardiac muscles undergoes less dilution because of the slower turnover of proteins.

There was a wide variation in $k_{s}$ (Table 3 ) among the tissues, an observation similar to that reported by Meier $e t$ al. (1981) and Noakes \& Young (1981). Among the tissues, the small intestine displayed the highest $k_{s}$. A high degree of metabolic activity and protein turnover in gastrointestinal tissue might be expected considering the swallowing of amniotic fluid by the fetus as well as the absorption of nutrients from the gastrointestinal tract as shown by Pitkin \& Reynolds (1975) and Char \& Rudolph (1979). This would suggest that in late gestation, even under in utero conditions, the digestive organs of the fetus are already functioning to a certain extent.

The high $k_{s}$ values and total RNA concentration in the liver indicate the high protein synthetic capacity and turnover of this tissue. Although the protein: RNA value in this tissue was comparatively lower than in the other tissues (Table 5) the RNA activity, which represents 
the extent to which the protein synthetic capacity is expressed (g protein/g RNA per d; Table 5) was high. This possibility indicates that much of the synthesized protein is exported. The lungs also resemble the liver in this regard, suggesting the synthesis of extracellular surfactant proteins. Brain and kidney occupy an intermediate position (Table 3) with respect to $k_{s}$. Brain tissue showed the lowest RNA:DNA value (Table 5) but a higher protein: RNA value and RNA activity than liver and lung, indicating that the protein synthetic capacity is utilized to the maximum in this tissue. Compared with other tissues, both skeletal and cardiac muscles showed relatively low $k_{8}$ values $(14-26 \%)$. These values are comparable to the $k_{s}$ of $23-35 \% / d$ reported in newborn or young lambs (Soltesz et al. 1973; Arnal, 1977). As the lambs grow older the muscle $k_{s}$ drops to 2-7\%/d (Buttery et al. 1975; Arnal, 1977; Davis et al. 1981). The DNA unit size (protein:DNA) is, however, highest in the muscles and liver, indicative of hypertrophy of the cells. In spite of the high protein: RNA value in the muscles which represents a high protein synthetic capacity, the actual expression of this ability appears to be low as indicated by the relatively low RNA activity (Table 5) and $k_{s}$ (Table 3).

The whole-body rate of protein synthesis of $63 \mathrm{~g} / \mathrm{d}$ per $\mathrm{kg}$ observed in the present study is higher than the values of $38.6 \mathrm{~g} / \mathrm{d}$ per $\mathrm{kg}$ reported by Noakes \& Young (1981) or $15 \mathrm{~g} / \mathrm{d}$ per $\mathrm{kg}$ reported by Meier et al. (1981) for fetuses in late gestation. Nevertheless, these values from all three studies on fetal sheep contrast sharply with the low rate of whole-body protein synthesis of $6.9 \mathrm{~g} / \mathrm{d}$ per $\mathrm{kg}$ reported in adult sheep (Reeds \& Lobley, 1980). Values ranging from 45 to $78.9 \mathrm{~g} / \mathrm{d}$ per $\mathrm{kg}$ have been reported for immature rats (Garlick, 1980) and 33 g/d per $\mathrm{kg}$ for newborn lambs (Soltesz et al. 1973). When the present values are expressed on a metabolic body size basis, the whole-body protein synthetic rate amounts to $52 \mathrm{~g} / \mathrm{kg}$ body-weight ${ }^{0.75}$ per $\mathrm{d}$ which is close to the value of $49 \mathrm{~g} / \mathrm{kg}$ body-weight ${ }^{0.75}$ per $\mathrm{d}$ reported by Soltesz et al. (1973) for newborn lambs.

Apart from the inherent variables associated with the physiological condition of the preparations, the major difference appears to lie in the isotopes employed and the methodology used in estimating the kinetic indices. The fetuses used by Noakes \& Young (1981) were infused 24-48 hafter surgery which may not provide adequate time for recovery from the surgical trauma (Kitts et al. 1979). This might influence the dynamics of protein turnover.

It is also noteworthy that although $\left[{ }^{14} \mathrm{C}\right] \mathrm{lysine}$ was used for infusion in both cases, the lysine flux values and whole-body rates of protein synthesis reported by Meier et al. (1981) are approximately three times lower than those obtained by Noakes \& Young (1981) for fetuses of similar age. Methodological and analytical differences and variability in the physiological status of the preparations may account for the differences observed.

\section{Energy cost of protein synthesis in the fetus}

The efficiency of whole-body protein synthesis is the ratio, rate of protein deposition: total rate of protein synthesis. Based on the comparative slaughter results of Rattray et al. (1974) it can be determined that the sheep fetus at $120 \mathrm{~d}$ of gestation gains approximately $6-9 \mathrm{~g} / \mathrm{d}$ per $\mathrm{kg}$. This is similar to the rate of $9.5 \mathrm{~g} / \mathrm{d}$ per $\mathrm{kg}$ reported by Lemons $\mathrm{et}$ al. (1976) based on the net $\alpha-\mathrm{NH}_{2}-\mathrm{N}$ uptake by the fetus. In the present study the net $\alpha-\mathrm{NH}_{2}-\mathrm{N}$ uptake by the fetus was determined in one preparation by multiplying the arterio-venous concentration difference by the umbilical blood flow. It was found that $1.59 \mathrm{~g} \alpha-\mathrm{NH}_{2}-\mathrm{N} / \mathrm{d}$ per kg was retained by the fetus which is equivalent to a protein- $\mathrm{N}$ retention of $9.9 \mathrm{~g} / \mathrm{d}$ per $\mathrm{kg}$.

Thus the rate of whole-body protein synthesis in the fetus $(63 \mathrm{~g} / \mathrm{d} \mathrm{per} \mathrm{kg})$ is at least six to eight times more than the rate of protein deposition $(6-10 \mathrm{~g} / \mathrm{d} \mathrm{per} \mathrm{kg})$. However, the significance of protein turnover in the fetus should be considered in relation to its contribution to the energy economy of the fetus. Using the value of $4.5 \mathrm{~kJ} / \mathrm{g}$ as the cost 
of protein synthesis (Webster, 1977), and a heat production of $368 \mathrm{~kJ} / \mathrm{d}$ per kg (Battaglia \& Meschia, 1978), it may be calculated that whole-body protein turnover contributes at least $55 \%$ to total heat production. This is similar to the values reported for lambs $(25-42 \%$; Soltesz et al. 1973; Davis et al. 1981) and much higher than that in older sheep (4.5-14\%; Buttery et al. 1975; MacRae \& Reeds, 1977). Further, as suggested by Davis et al. (1981), because of the high rate of protein turnover as compared to the rate of deposition, even small changes in the former are likely to result in larger changes in protein deposition. The methodology used in this investigation can be used to investigate intrauterine growth retardation by monitoring changes in fetal rates of protein synthesis as influenced by nutritional and endocrine status.

The authors wish to thank the Natural Sciences and Engineering Research Council of Canada for financial support of this project and Miss Sandy Heindze for technical assistance.

\section{REFERENCES}

Ambrose, J. A. (1974). Clinical Chemistry 20, 505-510.

Anand, R. S., Sperling, M. A., Ganguli, S. \& Nathanielsz, P. W. (1979). Pediatric Research 13, 783-787.

Arnal, M. (1977). European Association for Animal Production 22, 35-37.

Arthur, G. H. (1981). In Fetal Growth Retardation, pp. 219-230 [F. A. Van Assche and W. B. Robertson, editors]. Edinburgh: Churchill Livingstone.

Battaglia, F. C. \& Meschia, G. (1978). Physiological Reviews 58, 499-527.

Broad, T. E. \& Davies, A. S. (1981). Animal Production 32, 235-243.

Bryant, D. T. W. \& Smith, R. W. (1982). Journal of Agricultural Science, Cambridge 98, 639-643.

Buttery, P. J., Beckerton, A. \& Lubbock, M. H. (1977). European Association for Animal Production 22, 32-34.

Buttery, P. J., Beckerton, A., Mitchell, R. M., Davies, K. \& Annison, E. F. (1975). Proceedings of the Nutritional Society 34, 91A-92A.

Char, V. C. \& Rudolph, A. M. (1979). Pediatric Research 13, 1018-1023.

Cheek, D. B. (1975). Fetal and Postnatal Cellular Growth. New York: John Wiley and Sons.

Comline, R. S. \& Silver, M. (1970). Journal of Physiology, London 209, 567-586.

Davis, S. R., Barry, T. N. \& Hughson, G. A. (1981). British Journal of Nutrition 46, 409-419.

Faber, J. J. \& Woods, L. L. (1981). Journal of Theoretical Biology 89, 433-448.

Garlick, P. J. (1980). In Protein Deposition in Animals, pp. 51-67 [P. J. Buttery and D. B. Lindsay, editors]. London: Butterworths.

Garlick, P. J., Burk, T. L. \& Swick, R. W. (1976). American Journal of Physiology 230, 1108-1112.

Garlick, P. J. \& Marshall, I. (1972). Journal of Neurochemistry 19, 577-583.

Gold, D. V. \& Shochat, D. (1980). Analytical Biochemistry 105, 121-125.

Goodwin, J. F. (1968). Clinical Chemistry 14, 1080-1090.

Gresham, E. L., Rankin, J. H. G., Makowski, E. L., Meschia, G. \& Battaglia, F. C. (1972). Journal of Clinical Investigation 51, 149-156.

Hodgson, J. C., Mellor, D. J. \& Field, A. C. (1980). Biochemical Journal 186, 739-747.

James, W. P. T., Garlick, P. J., Sender, P. M. \& Waterlow, J. C. (1976). Clinical Science and Molecular Medicine 50, 525-532.

Kitts, D. D. \& Krishnamurti, C. R. (1982a). Canadian Journal of Animal Science 62, 409-415.

Kitts, D. D. \& Krishnamurti, C. R. (1982b). Canadian Journal of Animal Science 62, 397-408.

Kitts, D. D., Krishnamurti, C. R. \& Kitts, W. D. (1979). Canadian Journal of Animal Science 59, 265-271.

Koong, L. J., Garrett, W. N. \& Rattray, P. V. (1975). Journal of Animal Science 41, 1065-1068.

Lemons, J. A., Adcock, E. W., Jones, M. D., Naughton, M. A., Meschia, G. \& Battaglia, F. C. (1976). Journal of Clinical Investigation 58, 1428-1434.

Lobley, G. E., Milne, V., Lovie, J. M., Reeds, P. J. \& Pennie, K. (1980). British Journal of Nutrition 43, 491-502.

Lodge, G. A. \& Heaney, D. P. (1973). Canadian Journal of Animal Science 53, 95-105.

McDonald, I., Robinson, J. J. \& Fraser, C. (1981). Journal of Agricultural Science, Cambridge 96, 187-194.

MacRae, J. C. \& Reeds, P. J. (1977). In Protein Deposition in Animals, pp. 225-249 [P. J. Buttery and D. B. Lindsay, editors]. London: Butterworths.

Meier, P. R., Peterson, R. G., Bonds, D. R., Meschia, G. \& Battaglia, F. C. (1981). American Journal of Physiology 240, E320-E324.

Mellor, D. J. \& Matheson, I. C. (1979). Quarterly Journal of Experimental Physiology 64, 119-131.

Mellor, D. J. \& Murray, L. (1981). Research in Veterinary Science 30, 198-204.

Mellor, D. J. \& Murray, L. (1982). Research in Veterinary Science 32, 379-382. 
Noakes, D. E. \& Young, M. (1981). Research in Veterinary Science 31, 336-341.

Pitkin, R. M. \& Reynolds, W. A. (1975). American Journal of Obstetrics and Gynecology 123, 356-363.

Rattray, P. V., Garrett, W. N., East, N. E. \& Hinman, N. (1974). Journal of Animal Science 36, $613-626$.

Rattray, P. V., Robinson, D. W., Garrett, W. N. \& Ashmore, R. C. (1975). Journal of Animal Science 40, $783-787$.

Reeds, P. J., Cadenhead, A., Fuller, M. F., Lobley, G. E. \& McDonald, J. D. (1980). British Journal of Nutrition 43, 445-455.

Reeds, P. J, \& Lobley, G. E. (1980). Proceedings of the Nutritional Society 39, 43-52.

Richardson, C. (1978). In The Veterinary Annual, pp. 101-106 [C. S. Grunsell and F. W. G. Hill, editors]. Bristol: John Wright and Sons.

Robinson, J. J. (1977). Proceedings of the Nutritional Society 36, 9-16.

Robinson, J. J. (1981). Livestock Production Science 8, 273-281.

Robinson, J. J. \& McDonald, I. (1979). Annales de Biologie Animale, Biochimie et Biophysique 19, $225-234$.

Schaefer, A. L. \& Krishnamurti, C. R. (1982a). Canadian Federation of Biological Societies, Proceedings 25, 80A.

Schaefer, A. L. \& Krishnamurti, C. R. (1982 b). Canadian Journal of Animal Science 62, 787-797.

Schaefer, A. L. \& Krishnamurti, C. R. (1982c). Canadian Journal of Animal Science 62, 1223-1227.

Simon, O., Munchmeyer, R., Bergner, H., Zebrowska, T. \& Buraczewska, L. (1978). British Journal of Nutrition 40, 243-252.

Sokal, R. R. \& Rohlf, F. J. (1969). Biometry. W. H. Freeman and Comp: San Francisco.

Soltesz, Gy., Joyce, J. \& Young, M. (1973). Biology of the Neonate 23, 139-148.

Steel, R. G. D. \& Torrie, J. H. (1960). Principles and Procedures of Statistics. New York: McGraw Hill.

Waterlow, J. C., Garlick, P. J. \& Millward, D. J. (1978). Protein Turnover in Mammalian Tissues and in the Whole Body. New York: Elsevier/North Holland.

Webster, A. J. F. (1977). Proceedings of the Nutritional Society 36, 53-59.

Zak, R., Martin, A. F. \& Blough, R. (1979). Physiological Reviews 59, 407-447. 